\title{
EDUKASI PENTINGNYA MELAKUKAN HEMODIALISA SECARA RUTIN BAGI PASIEN GAGAL GINJAL KRONIK
}

DOI: https://doi.org/10.33024/jkpm.v4i4.4076

\author{
Indra Maulana ${ }^{1}$, Iwan Shalahuddin ${ }^{2}$, Taty Hernawaty ${ }^{3}$ \\ ${ }^{1,2}$ Fakultas Keperawatan Universitas Padjadjaran Kampus Garut \\ ${ }^{3}$ Fakultas Keperawatan Universitas Padjadjaran Kampus Jatinangor
}

Disubmit: 19 Maret 2021 Diterima: 07 April 2021 Diterbitkan: 03 Agustus 2021

Email: kang.indra476@gmail.com, shalahuddin@unpad.ac.id, taty.hernawaty@unpad.ac.id

\begin{abstract}
ABSTRAK
Gagal ginjal kronis merupakan gangguan fungsi renal yang progresif dan irreversibel dimana kemampuan tubuh gagal untuk mempertahankan metabolisme dan keseimbangan cairan dan elektrolit sehingga terjadi uremia. Cemas (ansietas) adalah suatu keadaan patologik yang ditandai oleh perasaan ketakutan diikuti dan disertai tanda somatik. Kecemasan juga merupakan respon terhadap suatu ancaman yang sumbernya tidak diketahui, internal, samarsamar, atau konfliktual. Kecemasan salah satunya disebabkan oleh gangguan biologik, seperti penyakit ginjal kronik (PGK) yang membutuhkan hemodialisis. Penderita hemodialisis mengalami kecemasan, salah satunya dapat diakibatkan oleh kronisitas penyakit. Tujuan kegiatan adalah untuk memberikan sebuah pemahaman tentang perlunya dilakukan perawatan hemodialisa bagi pasien yang menjalani Hemodialisa di RSU Garut. Sasaran utama atau target khusus dari kegiatan ini adalah pasien gagal ginjal kronis yang dilakukan hemodialisa di ruang hemodialisa RSUD dr. Slamet Garut. Metode yang digunakan dalam kegiatan ini adalah melalui pemutaran video, ceramah, dan diskusi serta tanya jawab. Kegiatan yang dilaksanakan pada bulan Juli 2018 di ruang kelas Demonstrasi Kampus Unpad Garut. peserta yang hadir sebanyak 20 orang. Acara diawali dengan pembukaan oleh kepala ruangan hemodialis, dan penjelasan tentang kegiatan yang akan dilaksanakan. lalu memperkenalkan para pemateri yang hadir. Selanjutnya pemateri mengajak peserta untuk menyaksikan tayangan video tentang testimony pasien gagal ginjal kronis dan bahaya gagal ginjal kronis pada tubuh manusia dan dilanjutkan dengan ceramah tentang pentingnya dilakukan hemodialisa pada pasien gagal ginjal kronis. Setelah pemutaraan video dan cermah tersebut selesai, maka dilakukan diskusi dan tanya jawab seputar isi materi kegiatan. Acara ditutup dengan pembagian hadiah bagi tiga orang peserta yang paling aktif selama mengikuti kegiatan. Kegiatan ini memberikan hasil tentang pemahaman tentang keuntungan hemodialisa bagi pasien gagal ginjal kronis.
\end{abstract}

Kata Kunci: Cemas, Edukasi, Gagal Ginjal Kronis, Hemodialisa 


\begin{abstract}
Chronic renal failure is a progressive and irreversible impairment of renal function in which the body's ability to fail to maintain metabolism and fluid and electrolyte balance resulting in uremia. Anxiety (anxiety) is a pathological condition characterized by a feeling of fear followed and accompanied by somatic signs. Anxiety is also a response to a threat whose source is unknown, internal, vague, or conflictual. One of the causes of anxiety is biological disorders, such as chronic kidney disease (CKD) which requires hemodialysis. Hemodialysis sufferers experience anxiety, one of which can be caused by the chronicity of the disease. The purpose of the activity is to provide an understanding of the need for hemodialysis treatment for patients undergoing hemodialysis at Garut General Hospital. The main target or specific target of this activity is chronic kidney failure patients who are undergoing hemodialysis in the hemodialysis room of dr. Slamet Garut. The method used in this activity is through video playback, lectures, and discussion and question and answer. Activities carried out in July 2018 in the Garut Campus Demonstration classroom. participants who attended were 20 people. The event begins with an opening by the head of the hemodial room, and an explanation of the activities to be carried out. then introduced the presenters. Furthermore, the speaker invited the participants to watch a video about the testimony of chronic kidney failure patients and the dangers of chronic kidney failure in the human body and continued with a lecture on the importance of hemodialysis in chronic kidney failure patients. After the screening of the video and lecture was completed, a discussion and question and answer was held about the content of the activity material. The event was closed by distributing prizes to the three most active participants during the activity. This activity provides an understanding of the benefits of hemodialysis for patients with chronic renal failure.
\end{abstract}

Keywords: Anxiety, Education, Chronic Renal Failure, Hemodialysis

\title{
1. PENDAHULUAN
}

Di Indonesia, penderita yang mengalami penyakit ginjal kronis (PGK) dan menjalani terapi hemodialisis mengalami peningkatan. Berdasarkan survey yang dilakukan oleh Perhimpunan Nefrologi Indonesia (PERNEFRI) seperti dikutip dalam Wiguno dan Suhardjono (2009), terdapat 18 juta orang di Indonesia menderita PGK. Perkiraan WHO pada tahun 2012, angka harapan hidup penduduk Indonesia mencapai 71 tahun, dan pada tahun yang sama WHO memperkirakan angka kematian yang disebabkan oleh penyakit kronis di Indonesia mencapai 54\% dari seluruh penyebab kematian, melebihi angka kematian yang disebabkan karena penyakit menular dan kecelakaan. Salah satu penyakit kronis yang angka kejadiannya diperkirakan meningkat setiap tahunnya adalah GGK (Sundara, 2015).

Gagal ginjal sendiri terbagi menjadi dua, yakni Penyakit Ginjal Kronik (PGK), dan juga Gagal Ginjal Akut. PGK merupakan kondisi dimana terdapat penurunan fungsi ginjal akibat berbagai sebab. Penurunan fungsi itu biasanya terjadi secara perlahan namun progresif dan irreversible berlangsung lebih dari tiga bulan, hingga pada suatu waktu ginjal pun tidak dapat menjalankan fungsinya. Sedangkan gagal ginjal akut kemunculannya bersifat mendadak, 
umumnya dapat membaik kembali seperti sedia kala, namun jika tidak ditangani dengan tepat akan berakhir menjadi PGK (Anggraini, 2016).

Insiden PGK bervariasi di berbagai negara dengan jumlah antara 100-150 per satu juta populasi per tahun di Eropa, 300 per satu juta populasi per tahun di Amerika Serikat ,dan 400 per satu juta populasi per tahun di Taiwan. Gambaran epidemiologis PGK di Indonesia kurang lebih serupa. Jumlah pasien yang didiagnosis sebagai PGK di RSUD Dr. Soetomo Surabaya juga mengalami kenaikan dalam empat tahun terakhir, dari 332 pada tahun 2008 menjadi 4.535 pada tahun 2012. Jumlah kunjungan di Instalasi hemodialisis meningkat dari 7.590 pada tahun 2008 menjadi 23.811 kunjungan pada tahun 2012. Morbiditas dan mortalitas pasien PGK mengalami peningkatan yang nyata sebagai konsekuensi tingginya risiko penyakit kardiovaskuler (Karangora, et al, 2017).

Laju kematian per tahun pasien gagal ginjal terminal dengan hemodialisis tiga kali per minggu berkisar antara 14 dan 26\% di Eropa dengan lebih dari $50 \%$ penyebabnya adalah komplikasi kardiovaskuler. Mortalitas kardiovaskuler pada PGK 10 sampai 20 kali lebih tinggi dari populasi umum. Pembiayaan untuk penanganan PGK beserta komplikasinya akhirnya menjadi suatu masalah yang penting, khususnya karena disertai dengan peningkatan prevalensi PGK (Sutopo, 2016)

Hemodialisis merupakan salah satu jenis terapi pasien gagal ginjal yang banyak dijalani oleh penderita di Indonesia. Hemodialisis digunakan untuk 'menggantikan' sebagian fungsi ginjal. Walau tidak sesempurna fungsi asli ginjal, hemodialisis dapat membantu menormalkan kembali keseimbangan cairan, membuang sisa metabolisme tubuh, menyeimbangkan asam-basaelekterolit dalam tubuh, dan membantu mengendalikan tekanan darah. Hanya saja hemodialisis tidak dapat memproduksi sejumlah hormon yang dibutuhkan untuk metabolisme tubuh (Dewi, \& Anita, 2015).

Proses dialisis dilakukan dengan mempertukarkan berbagai zat yang terkandung dalam darah dan cairan dialisat (cairan yang menyerupai cairan tubuh yang normal). Proses pertukaran tersebut terjadi pada bagian mesin hemodialisis yang disebut dialiser melalui berbagai tahap antara lain proses difusi dan ultrafiltrasi. Menjalani hemodialisis yang cukup (adekuat) sangat penting bagi penderita gagal ginjal. Jika hemodialisis yang dijalani tidak adekuat, proses hemodialisis akan terganggu dan menyebabkan munculnya gejala-gejala seperti gatal di kulit, mual dan muntah, penurunan nafsu makan, bengkak pada tungkai, sesak nafas dan lain-lain. Prosedur hemodialisis sendiri biasanya berlangsung sekitar empat sampai lima jam dan dilakukan sebanyak dua sampai tiga kali seminggu (Aisara, et al, 2018)

Hemodialisis (HD) berperan penting bagi penderita penyakit ginjal. Pada penderita penyakit ginjal, organ ginjal mengalami penurunan fungsi hingga akhirnya tidak mampu bekerja lagi sama sekali. Pada prinsipnya hemodialisis adalah terapi untuk menggantikan kerja dari ginjal yaitu menyaring dan membuang sisa-sisa metabolisme dan kelebihan cairan, membantu meyeimbangkan unsur kimiawi dalam tubuh serta membantu menjaga tekanan darah (Alchusna dan Susilaningrum, 2013). maka dengan 
itu betapa pentingnya pasien dengan Gagal Ginjal Kronik untuk melakukan hemodialisa (Sujana, \& Kadoyu, 2020).

Pelaksanaan hemodialisa sepanjang hidup membuat seseorang yang melaksanakannya merasa tertekan, jenuh, putus asa, gelisah dan cemas yang mempengaruhi fakktor fisik, psikis, sosial (Martiningsih, F. M., \& JIWA, P, 2018). Untuk mengetahui sejauhmana derajat depresi seseorang apakah ringan atau berat sekali, orang menggunakan alat ukur (isntrumen) yang dikenal dengan nama Hamilton Rating Scale for Depression (HRS-D). Alat ukur ini terdiri dari 21 kelompok gejala yang masing-masing kelompok dirinci lagi dengan gejala-gejala yang lebih spesifik (Hamilton, (1986).

Pengawasan jangka panjang setiap pasien hemodialisa reguler sangat penting karena hemodialisa reguler ini dapat mempengaruhi kualitas hidup optimal. Pengawasan tersebut berhubungan dengan aspek medis, sosial professional dan psikologis (Wahyuni \& Wahyuni, 2015).

Tujuan dari Pengabdian pada masyarakat ini adalah Mengidentifikasi tingkat kecemasan pasien gagal ginjal kronis yang dilakukan haemodialisa dan Memberikan edukasi untuk mengurangi kecemasan pada pasien gagal ginjal kronis yang dilakukan haemodialisa di ruang haemodilasis RSU dr.Slamet Garut

\section{MASALAH}

Minimnya informasi masyarakat tentang penyakit ginjal juga menjadi penyebab lain. Dengan sifat PGK yang tanpa gejala di stadium awal, membuat masyarakat baru menyadari dirinya menderita gagal ginjal saat sudah stadium akhir. Alhasil, penanganan lebih lanjut harus dilakukan, termasuk salah satunya dengan terapi pengganti fungsi ginjal yaitu dialisis/cuci darah, meliputi hemodialisis, peritoneal dialisis, dan transplantasi ginjal (cangkok ginjal). Untuk kali ini kita akan membahas mengenai hemodialisis.

Ada beberapa kasus gagal ginjal akut (mendadak), hemodialisis memang hanya dilakukan sementara hingga penyakit dasar tertangani dan fungsi ginjal kembali membaik, namun pada PGK stadium akhir dimana kerusakan ginjal telah terjadi secara permanen, hemodialisis akan dilakukan selama masa hidup pasien secara berkelanjutan, ini juga berkaitan dengan pertanyaan tentang berapa lama seorang pasien dapat hidup setelah menjalani hemodialisis (Hidayat, 2019).

Lama harapan hidup pasien tetap tidak dapat ditentukan karena ada banyak faktor yang mempengaruhi. "Faktor itu meliputi faktor usia, faktor penyakit dasar yang dimiliki, kondisi ginjal saat hemodialisis, serta tingkat kepatuhan menjalani aturan dan terapi, termasuk infeksi yang bisa saja terjadi," Dr. Thaha menjelaskan. Meski begitu tambahnya, dengan melakukan hemodialisis maka harapan dan kualitas hidup pasien akan semakin tinggi.

Di Indonesia, hemodialisis merupakan jenis terapi yang paling banyak digunakan oleh penderita gagal ginjal (Indonesian Renal Registry, 2010), namun di sisi lain sebagian besar orang masih menganggap hemodialisis 
adalah hal yang menakutkan. Hemodialisis dianggap sebuah 'vonis' yang mematikan. Padahal hal tersebut tidak sepenuhnya benar. Menurut Dr. Thaha, anggapan itu muncul karena transfer informasi yang belum menyeluruh yang diterima masyarakat. Faktanya, justru bila tidak dilakukan (salah satunya) hemodialisis pada penderita PGK stadium akhir, harapan hidup penderita PGK akan semakin pendek

Berdasarkan latar belakang di atas, untuk meminimalisasi terjadinya dan dampaknya, perlu diberikan arahan dan pendidikan ilmu pengetahuan yang berkelanjutan, salah satunya dengan memberikan edukasi kesehatan tentang pentingnya melakukan hemodialisa secara rutin pada pasien GGK, sehingga secara tidak langsung dapat meningkatkan semangat harapan hidup untuk menjalani dan mengatasi keluhan psikologis dampak dari hemodialisa.

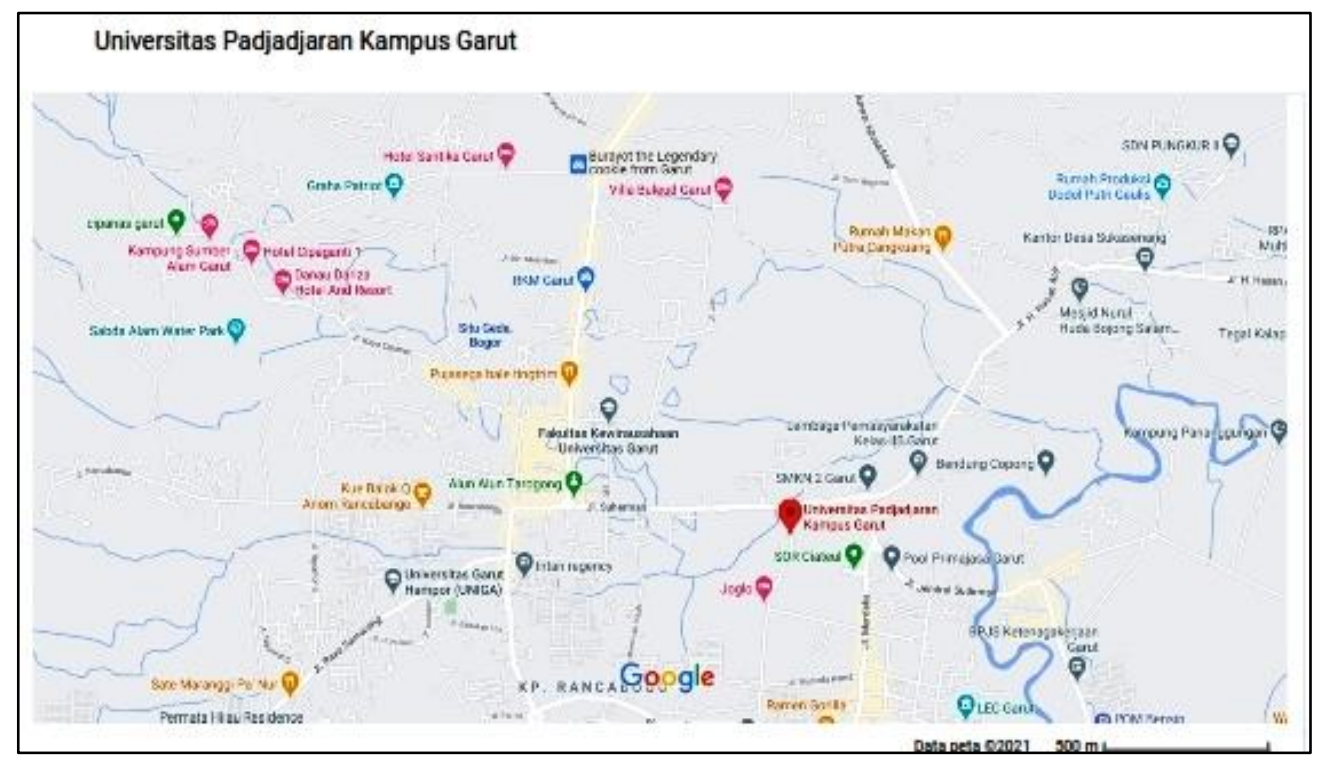

Gambar 2.1. Peta Lokasi Pelaksanaan Edukasi di Unpad Kampus Garut

\section{METODE.}

Subjek dalam pengabdian ini sasarannya adalah pada pasien dan keluarganya yang mengalami gagal ginjal kronik dengan tindakan hemodialisa di ruangan hemodialisa RSU dr.Slamet Garut. Tahap persiapan melakukan koordinasi dengan dengan Rumah Sakit dan Institusi Unpad kampus Garut untuk permohonan izin kegiatan, identifikasi mengenai keadaan umum, pengetahuan, perilaku serta upaya pentingnya melakukan hemodialisa secara rutin pada pasien GGK dan Mempersiapkan sumber daya yang dibutuhkan yang melibatkan mahasiswa Fakultas Keperawatan.

Tahap implementasi dengan merencanakan strategi komunikasi lalu kemudian dipilihlah penyuluhan edukasi dan motivasi sebagai langkah strategi yang diambil, dilakukan survei data-data pasien hemodialisa yang ada di RSUD dr. Slamet Garut, survei terhadap pengalaman pasien hemodialisa selama menjalani proses pengobatan, Menyusun media informasi leaflet mengenai pentingnya melakukan hemodialisa secara rutin yang disusun oleh tim pengabdian pada masyarakat, Melakukan Pre Test 
tentang pentingnya melakukan hemodialisa secara rutin, Melaksanakan penyuluhan kesehatan pentinggnya melakukan hemodialisa secara rutin. Media informasi bagi pasien gagal ginjal kronik ini disusun oleh tim pengabdian pada masyarakat dan Melakukan Post Test tentang pentingnya melakukan hemodialisa secara rutin. Metode yang dilakukan dalam edukasi kesehatan adalah penjelasan atau ceramah yang diberikan oleh pemateri kepada semua peserta dan diikiuti dengan tanya jawab, pemateri harus memastikan semua peserta mengerti materi yang telah disampaikan dengan memastikan kembali kepada peserta apabila ada hal-hal yang kurang jelas.

Metode yang digunakan antara lain Ceramah/ Lecture untuk mempermudah peserta untuk memahami isi dari materi yang akan disampaikan oleh mahasiswa sebagai Ilmu pengetahuan; Metode Tanya jawab yang merupakan usaha penyingkiran rintangan selama atau sesudah berlangsungnya masa ceramah. Hal ini untuk mempermudah para peserta menanyakan soal tentang materi yang diberikan; Metode Diskusi agar para peserta mampu memecahkan masalah yng dihadapi dari pertanyaan-pertanyaan yang diberikan dengan topik pembahasan materi. Metode diskusi juga bertujuan untuk tukar menukar gagasan, pemikiran, informasi/pengalaman diantara peserta, sehingga dicapai kesepakatan pokok-pokok pikiran (gagasan, kesimpulan), selanjutnya pemutaran video, diharapkan peserta dapat memahami, mengingat, sekaligus mendapatkan gambaran tentang pentingnya pelaksanaan hemodialisa secara rutin. Dengan diskusi langsung dan pemutaran video, maka akam menstimulasi semua panca indera para peserta.

\section{HASIL DAN PEMBAHASAN}

Berdasarkan hasil rekapitulasi hasil pengkajian kebutuhan belajar dapat terlihat bahwa ada sebagian peserta, kebutuhan belajar yang termasuk kedalam kebutuhan belajar : Perceived needs Karena ada sebagian mengetahui dampak dari tidak melakukan hemodialisa secara rutin bagi pasien GGK; Unperceived needs Karena ada sebagian peserta yang belum mengetahui dampak dari tidak melakukan hemodialisa secara rutin bagi pasien GGK; Misperceived needs Karena ada sebagian peserta yang mengetahui bahaya jika tidak melakukan hemodialisa secara rutin bagi pasien GGK, tetapi masih ada yang tidak mengetahui pentingnya melakukan hemodialisa secara rutin bagi pasien GGK. Data Rekapitulasi Hasil Pengkajian Kebutuhan Belajar Jumlah audience : 20 orang, Audience terdiri dari para pasien GGK beserta keluarganya yang melakukan hemodialisa di RSU dr.Slamet Garut.

Kegiatan edukasi kesehatan yang dilaksanakan pada hari Sabtu, 07 Juli 2018 pukul 09.00 - selesai WIB bertempat di ruang demonstrasi kampus Garut Universitas Padjadjaran, dilakukan secara langsung tatap muka. Kegiatan ini diawali dengan pembukaan oleh kepala ruangan hemodialis RSU dr.Slamet Garut, dan penjelasan tentang kegiatan yang akan dilaksanakan. lalu memperkenalkan para pemateri yang hadir. Selanjutnya pemateri mengajak peserta untuk menyaksikan tayangan video tentang testimony pasien gagal ginjal kronis dan bahaya gagal ginjal kronis pada tubuh manusia dan dilanjutkan dengan ceramah tentang pentingnya dilakukan hemodialisa pada pasien gagal ginjal kronis. Setelah pemutaraan video dan cermah tersebut 
selesai, maka dilakukan diskusi dan tanya jawab seputar isi materi kegiatan. Acara ditutup dengan pembagian hadiah bagi tiga orang peserta yang paling aktif selama mengikuti kegiatan. Kegiatan ini memberikan hasil tentang pemahaman tentang keuntungan hemodialisa bagi pasien gagal ginjal kronis.

Dalam acara ini, peserta diberi materi mengenai pentingnya melakukan hemodialisa secara rutin, bagi pasien GGK yang dihemodialisa. Seluruh peserta penyuluhan antusias mendengarkan penyuluhan yang disampaikan oleh Penyuluh dari Tim Universitas Padjadjaran. terbukti dengan banyaknya peserta yang mengajukan pertanyaan setelah pemberian materi. Acara ini juga dilengkapi dengan pemberian leaflet tentang pentingnya hemodialisa dan diet GGK. leaflet diberikan kepada pihak peserta dan ruangan hemodialisa untuk ditempel di ruang tunggu hemodialisa, dengan tujuan untuk senantiasa mengingatkan pasien dan keluarganya mengenai pentingnya melakukan hemodialisa. Keantusiasan peserta dalam mengikuti kegiatan penyuluhan ini diharapkan dapat memacu setiap individunya untuk termotivasi secara rutin melakukan hemodialisa,. Kesan penyuluhan menarik, karena banyaknya pertanyaan yang ditanyakan oleh peserta kepada tim penyaji, peserta cukup memahami materi yang disampaikan.

Evaluasi edukasi, peserta terlihat antusias saat pemberian materi berlangsung. Peserta mengikuti edukasi dengan senang hati karena metode edukasi dilaksanakan dengan menyenangkan. Kegiatan berjalan kondusif karena peserta memperhatikan materi yang disampaikan dengan baik. Hal ini dibuktikan dengan banyaknya peserta yang tertarik untuk menjawab pertanyaan ketika sesi tanya jawa.

Efektifnya fungsi media ajar yang digunakan dapat terlihat jelas oleh seluruh peserta. Karena edukasi dilakukan secara tatap muka langsung sehingga para peserta khususnya keluarga pasien dapat berinteraksi langsung dengan pemateri juga dengan peserta lainya. Hal ini dapat menjadikan keefektifan penjelasan materi. Respon peserta yang baik terlihat dengan antusias untuk mengikutinya dari awal hingga akhir kegiatan.

Kegiatan ini dilaksanakan melalui penyuluhan langsung, yaitu dengan pemebrian materi, pemutaran video dan diskusi secara langsung yang sekaligus bertukar pikiran diantara peserta yang hadir. edukasi ini dilakukan sesuai dengan rencana yang telah disusun. Upaya yang dilakukan merupakan bagian dari upaya untuk mengingatkan pentingnya melakukan hemodialisa secara rutin bagi pasien GGK. 


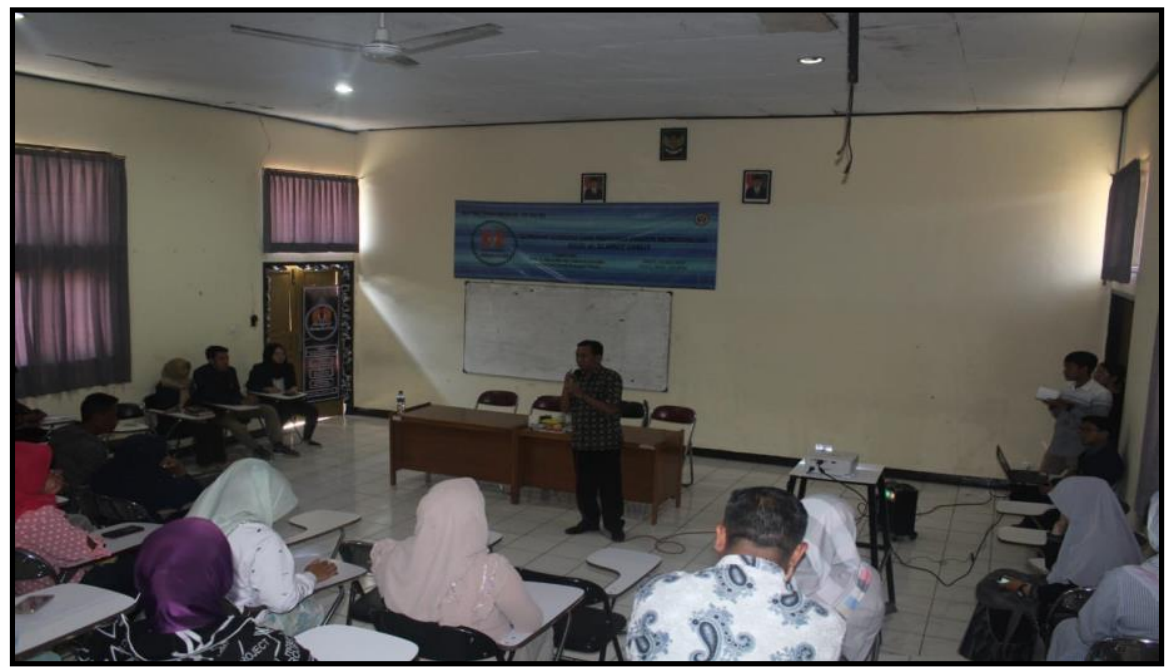

Gambar. 4.1. Poto Kegiatan Edukasi 1

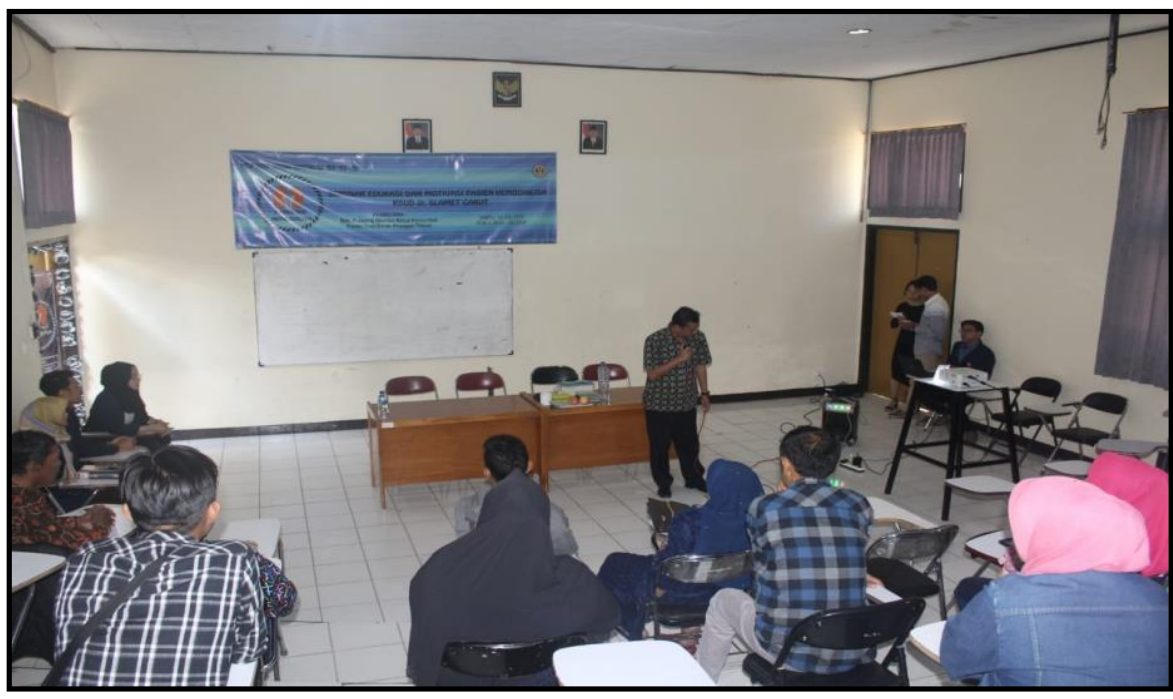

Gambar. 4.1. Poto Kegiatan Edukasi 2

\section{KESIMPULAN}

Kebutuhan belajar didapatkan bahwa kebutuhan belajar peserta pasien GGK dan keluarganya , meliputi kebutuhan belajar perceived needs, unperceived needs, dan misperceived needs. Pada proses pelaksanaan edukasi; peserta terlihat antusias saat pemberian materi berlangsung. Peserta mengikuti penyuluhan dengan senang hati karena penyuluhan dilaksanakan dengan tatap muka langsung dan bisa saling berinteraksi antara peserta. Kegiatan edukasi berjalan kondusif karena peserta memperhatikan materi yang disampaikan dengan baik.

Wujud kegiatan pelaksanaan yang diberikan meliputi tentang testimony pasien gagal ginjal kronis dan bahaya gagal ginjal kronis pada tubuh manusia dan pentingnya dilakukan hemodialisa pada pasien gagal ginjal kronis serta dampak bila tidak melakukan hemodialisa secara rutin. Selain itu, kegiatan yang dilakukan adalah interaksi secara langsung antara peserta dengan saling 
menceritakan pengalaman-pengalaman dilakukan hemodialisa serta mengutarakan hambatan-hambatan dan keluhan-keluhan yang dirasakan oleh masing-masing peserta, sehinga satu sama lainya bisa saling komunikasi untuk mengingatkan pentingnya hemodialisa.

\section{DAFTAR PUSTAKA}

Aisara, S., Azmi, S., \& Yanni, M. (2018). Gambaran klinis penderita penyakit ginjal kronik yang menjalani hemodialisis di RSUP Dr. M. Djamil Padang. Jurnal Kesehatan Andalas, 7(1), 42-50. http://jurnal.fk.unand.ac.id/index.php/jka/article/view/778

Alchusna, R. A., \& Susilaningrum, D. (2013). Pengukuran Tingkat Efisiensi Pelayanan Unit Hemodialisis di Rumah Sakit H1 dan H2. Jurnal Sains dan Seni ITS, 2(1),

D78-D82. http://ejurnal.its.ac.id/index.php/sains_seni/article/viewFile/3188/8 06

Anggraini, Y. D. (2016). Kualitas hidup pasien gagal ginjal kronis yang menjalani hemodialisis di RSUD Blambangan Banyuwangi. https: / / repository.unej.ac.id/handle/123456789/76659

Bayhakki, B., \& Hasneli, Y. (2018). Hubungan Lama Menjalani Hemodialisis dengan Inter-Dialytic Weight Gain (IDWG) pada Pasien Hemodialisis. Jurnal Keperawatan Padjadjaran, 5(3). http://jkp.fkep.unpad.ac.id/index.php/jkp/article/view/646

Dewi, S. P., \& Anita, D. C. (2015). Hubungan lamanya hemodialisa dengan kualitas hidup pasien gagal ginjal di RS PKU Muhammadiyah Yogyakarta (Doctoral dissertation, STIKES'Aisyiyah Yogyakarta). http://digilib.unisayogya.ac.id/234/

Hamilton, M. (1986). The Hamilton rating scale for depression. In Assessment of depression (pp. 143-152). Springer, Berlin, Heidelberg.

Hidayat, R. (2019). Fenomena pengalaman Religius: studi kasus penderita Gagal Ginjal Kronis di Mojokerto (Doctoral dissertation, UIN Sunan Ampel Surabaya). http://digilib.uinsby.ac.id/39019/

Indonesia, P. N. (2000). Penyakit Ginjal Kronik dan Glomerulopati: Aspek Klinik dan Patologi Ginjal. PERNEFRI, Jakarta.

Karangora, E., Seno, K., \& Partiningrum, D. L. (2017). Beberapa Faktor Risiko Penyakit Ginjal Kronik Di Rsud Wz Yohannes Kupang Periode 20102015 (Doctoral dissertation, Faculty of Medicine). http://eprints.undip.ac.id/57597/

Martiningsih, F. M., \& JIWA, P. (2018). Perbedaan Pengaruh Terapi Relaksasi Otot Progresif Dan Terapi Suportif Terhadap Kecemasan Orangtua Dengan Anak Hospitalisasi Di Rsud. Dr. R. Soedjono Selong Kabupaten Lombok Timur (Doctoral dissertation, Universitas Brawijaya).

Mirta, M., \& Handayani, R. S. (2015). Hubungan Kenaikan Berat Badan Interdialisis Dengan Kejadian Hipotensi Intradialisis Pada Pasien Cronic Kidney Desease Di Ruang Hemodialisa Rsud Dr. H. Abdul Moeloek Provinsi Lampung Tahun 2014. Holistik Jurnal Kesehatan, 9(1). http://ejurnalmalahayati.ac.id/index.php/holistik/article/view/149/9 1

Prasetya, G. (2018). Hubungan Penambahan Berat Badan Interdialisis Dengan Kejadian Hipertensi Intradialisis Pasien Gagal Ginjal Kronik Yang Menjalani Hemodialisa Rutin Di Rsud Dr. Soedirman Kebumen (Doctoral dissertation, STIKES MUHAMMADIYAH GOMBONG). 
http:/ /elib.stikesmuhgombong.ac.id/873/1/GIGIH\%2OPRASETYA\%20NIM \%20A21601442.pdf

Prodjosudjadi, W. Suhardjono.(2009). End-Stage Renal Disease In Indonesia: Treatment Development. Ethnicity \& Disease, 19.

Prodjosudjadi, W., Suwitra, K., Widiana, I. G. R., Loekman, J. S., Nainggolan, G., Prasanto, H. , ... \& WORKING GROUP OF THE INDONESIAN SOCIETY OF NEPHROLOGY. (2009). Detection and prevention of chronic kidney disease in Indonesia: initial community screening. Nephrology, 14(7), 669-674. https: / / onlinelibrary.wiley.com/doi/abs/10.1111/j.14401797.2009.01137.x

Sujana, T., \& Kadoyu, M. H. (2020). Hubungan Kepatuhan Hemodialisis Dengan Disfungsi Ereksi Pada Pria Usia Subur Di RSUD Ungaran. Jurnal Keperawatan Muhammadiyah, 5(2). http://103.114.35.30/index.php/JKM/article/view/5659

Sutopo, I. A. I. (2016). Analisis Faktor-Faktor Yang Berhubungan Dengan Kejadian Penyakit Ginjal Kronik (Studi Kasus di RSUP dr. Soeradji Tirtonegoro Klaten) (Doctoral dissertation, Universitas Negeri Semarang). http: / / lib.unnes.ac.id/28205/

Taruna, A. (2015). Hubungan Diabetes Melitus Dengan Kejadian Gagal Ginjal Kronik Di Rsud Dr. H. Abdoel Moeloek Provinsi Lampung Tahun 2013. Jurnal Medika Malahayati, 2(4), 164-168. http://ejurnalmalahayati.ac.id/index.php/medika/article/view/1987

Wahyuni, N. T., \& Wahyuni, T. (2015). Analisis Praktik Klinik Keperawatan pada Pasien Chronic Kidney Disease dengan Penerapan Terapi Benson Terhadap Kecemasan di Ruang Hemodialisa RSUD Abdul Wahab Sjahranie Samarinda. https://dspace.umkt.ac.id/handle/463.2017/1061 